\title{
Socio- Economic Profile and Constraints of Dairy Farmers in Cuddalore District of Tamil Nadu, India
}

\author{
R. Gopi ${ }^{1^{*}}$, A. Manivannan ${ }^{2}$, M. G. Sindhu ${ }^{3}$ and C. Soundararajan ${ }^{1}$ \\ ${ }^{1}$ Farmers Training Centre, Tamil Nadu Veterinary and Animal Sciences University, \\ Enathur, Kancheepuram, India \\ ${ }^{2}$ Veterinary College and Research Institute, Orathanadu, India \\ ${ }^{3}$ Veterinary College, Hassan, India \\ *Corresponding author
}

\section{A B S T R A C T}

Keywords

Socio- economic profile, Dairy

farmers,

Constraints, Cuddalore

Article Info

Accepted:

12 March 2020

Available Online:

10 April 2020
Dairy sector plays an important role in the Indian economy and in the socio economic development of the country. The present study was conducted to explore the socio-economic profile and constraints faced by the dairy farmers of Cuddalore district of Tamil Nadu. The data were collected from 60 dairy farming respondents through structured interview schedule developed for the study. The ex-post facto design research design was employed for the study. The study indicated that 46.67 per cent of the farmers belonged to old age group of above 45 years and were illiterate $(36.70 \%)$. Majority $(51.70 \%)$ of them had dairying and agriculture as their primary occupation and had more than 10 years of farming experience. Majority of the farmers had medium categories of cosmopoliteness and livestock possession $(85.00 \%$ and $68.33 \%)$ respectively. The major constraints faced by the respondents were lack of awareness about latest technologies, scarcity of grazing land and water in dairy farming and lack of veterinary extension services at field level.

\section{Introduction}

Dairy farming is the most suitable production system that has enormous potential to improve the socio-economic status of the large percentage of the rural population in the country. The livestock farming provides self- employment, beneficiary income and a nutritious health to the society in rural as well as urban areas. Livestock sector forms an important livelihood activity for most of the farmers, supporting agriculture in the form of critical inputs, contributing to the health and nutrition of the household, supplementing 
incomes, offering employment opportunities and finally being a dependable "bank on hooves" in times of need (Annual Report, 2017-18). India is endowed with largest livestock population in the world. There were about 299.9 million bovines, 65.06 million sheep, 135.17 million goats, 10.29 million pigs and other livestock and poultry which totally constitute about 512.05 million numbers as per $19^{\text {th }}$ livestock census in India.

Subsequently total livestock population has decreased by about 3.33 per cent as per GOI, 2014 report. Similarly, $19^{\text {th }}$ livestock census showed that there was decrease in cattle population over 2007 to 2012 from 11.18 million to 8.81 million numbers in Tamil Nadu also. There was a 21.22 per cent decrease in number of cattle during the inter census period 2007- 2012in Tamil Nadu (GOI, 2014). In this regard, studying the socio-economic profile and constraints of farmers would provide insights to assess the actual ground status of farmers that reflects their livelihood. Keeping these things in mind, the study was conducted to explore the socio-economic profile and constraints faced by dairy farmers of Cuddalore district of Tamil Nadu.

\section{Materials and Methods}

The study was conducted in Mangalore block of Cuddalore district of Tamil Nadu. Out of 13 blocks of Cuddalore district, Mangalore block was purposively selected for the study due to easy access to the researcher, familiarity to culture, local language and access to the infrastructure in the study area. Again from the Mangalore block, five villages were selected randomly. Finally, 12dairy farmers from each village were selected randomly, thus constitute a sample size of 60 dairy farmers for the study. Expost facto design research design was employed for the study since the variables chosen have already occurred and the data were collected through structured interview schedule which was developed and administrated for the study. A total of thirteen variables were selected for this study viz., age, sex, level of education, family type, family size, occupation, land holding, dairy farming experience, livestock possession, social participation, extension participation, cosmopoliteness and innovativeness. The data were analyzed with the help of frequency, percentage, mean and standard deviation.

Garrett's ranking technique was followed to analyze the constraints perceived by the dairy farmers in dairy farming. The farmers were asked to rank the factors that were limiting the dairy farming. These orders of merit were transformed into units of scores by using the following formula.

Per cent position $(\%)=100\left(\mathrm{R}_{\mathrm{ij}}-0.50\right) / \mathrm{N}_{\mathrm{j}}$ Where, $R_{i j}$ - Rank given for the $i^{\text {th }}$ factor by the $\mathrm{j}^{\text {th }}$ individual.

The percent position is converted into scores by referring to the table given by Garrett and Woodworth (1969). Then for each factor the scores of the individual respondents were added together and divided by the total number of respondents for whom scores were added. These mean scores for all the factors were arranged in descending order and the most influencing factor were identified through the ranks assigned.

\section{Results and Discussion}

\section{Socio- economic profile of dairy farmers}

\section{Age}

It is noticed from the Table 1 that nearly half (46.67\%) of the respondents belonged to old age group followed by middle $(33.33 \%)$ and young $(20.00 \%)$ age groups. Kalaivani et al., 
(2017) also reported that old age group farmers were more interested in rearing livestock and other farming activities.

\section{Sex}

More than one half $(51.70 \%)$ of the respondents were female and rest of them were males $(48.30 \%)$. Regarding the sex of the respondents, it is quite interesting to note that most of the activities in animal husbandry were carried out by the women but the responses given by female respondents in the study area.

\section{Education}

Study revealed that 36.70 per cent of the respondents were illiterates and their education categories were followed by middle $(30.00 \%)$, primary $(23.30 \%)$, can read only $(5.00 \%)$, can read and write $(3.30 \%)$ and high school $(1.70 \%)$ categories.

\section{Family type}

More than three-fourths $(78.30 \%)$ of the respondents belonged to nuclear family and the rest were $(21.70 \%)$ belonged to joint family. In recent days married young couples would like to live in freedom and reluctant to take parents responsibility which may be the reason for increasing nuclear families in social system (Chandrasekar et al., 2017). The results are in accordance with the findings of Kalaivani et al., (2017) that middle and young age people move out for employment in nonfarm sector and they settle their life in the work place itself which could be the possible reasons for more number of nuclear families.

\section{Family size}

More than three-fourths $(78.30 \%)$ of the respondents belonged to family size up to 5 members family and the remaining (21.70\%) belonged to more than 5 in family members.

\section{Occupation}

More than one half $(51.67 \%)$ of the respondents had dairying along with agriculture followed by dairying and agriculture with other family activities (26.66 $\%)$ and dairying alone $(21.67 \%)$ as their occupation. This finding derives support from the results of Chandrasekar et al., (2017) that dairy farming alone could not provide significant income; hence the respondents were involved in other occupations.

\section{Land holding}

One-third $(33.33 \%)$ of the respondents belonged to marginal farmers category followed by landless $(26.70 \%)$ and small farmer $(20.00 \%)$ category and the rest 13.30 per cent of them were in large farmer category.

\section{Dairy farming experience}

About 45.00 per cent of the farmers had high level of farming experience followed by medium $(35.00 \%)$ and low $(20.00 \%)$ level of farming experience respectively. The reason could be due to the farmers involvement in livestock rearing in their beginning of life itself and also they experienced improvement in their livelihood with dairying.

\section{Livestock possession}

Majority of the respondents (68.33\%) belonged to medium category followed by low $(18.33 \%)$ and high $(13.34 \%)$ categories.

\section{Social participation}

Majority of them $(75.00 \%)$ were members in the village dairy co-operatives. None of the farmers hold any position other than 
membership in any organisation. It was concluded that the farmers felt social participation play a crucial role in knowledge and awareness of new technologies in dairy farming practices. The findings support the results of Kalaivani et al., (2017) that dairy cattle being one of the major livestock reared by the respondents, most of them would have become members of dairy co-operatives to avail the service of this institution. This might be the reason for more number of respondents having membership in one organisation.

\section{Extension participation}

Exactly one-half $(50.00 \%)$ of the respondents had low level of extension participation and followed by medium level of extension participation $(41.67 \%)$ and the rest 8.33 per cent of the respondents had high level of extension participation. The reason could be that dairy farmers face lack of motivation regarding field visit, exhibitions, demonstrations, study tour and training programmes.

\section{Cosmopoliteness}

More than three-fourths $(85.00 \%)$ of the respondents belonged to medium level of cosmopoliteness, whereas, 8.33 per cent and 6.67 per cent of the respondents had low and high level of categories respectively. The result indicated that most of the farmers were seeking information from outside of their farming community in the study area.

\section{Innovativeness}

Nearly three-fourths $(73.34 \%)$ of the respondents adopted innovations after seeing the adoption of other farmers followed by preferred to wait and taken their own time $(23.33 \%)$ and adopt an innovations as soon as it they know (3.33\%). Most of the dairy farmers preferred to adopt innovations after seeing the benefits of adoption of other farmers.

\section{Constraints encountered by dairy farmers in dairying}

It is evident from the table 2, the first and foremost constraint faced by the dairy farmers was lack of knowledge in latest technologies with a mean score of 65.62. Most of them had lack of knowledge in the latest dairy feeding and management practices in the study area. Farmers are not aware of providing mineral mixture and balanced feeding and timely vaccination to their animals. In this era of modernization there is a need to create awareness among the latest dairy technologies to the farmers. The second important constraint was scarcity of grazing land and water (63.45) because most of the farmers were marginal and landless farmers in this study area. In recent days, increased human population, industrialization and urbanisation are the reasons for scarcity of grazing land and water.

The next important constraints were lack of veterinary extension services at field level (60.05) and lack of knowledge of available information sources with a mean score of 54.55. Manivannan (2008) also reported that the lack of proper extension support for livestock oriented activities in field level. The policy makers and administrators may take the necessary steps to fill up the existing vacant posts of Veterinary Assistant Surgeons post at block or village level and Veterinary University as well as Animal Husbandry Department can implement suitable awareness programmes regarding latest dairy technologies. Information kiosk at village level should be established at dairy cooperatives for easy accessing the latest dairy information by the dairy farmers and also the advantages of using social media application for knowledge dissemination can be explored by concerned Scientists. 
Table.1 Profile of dairy farmers in Cuddalore district $(n=60)$

\begin{tabular}{|c|c|c|c|c|}
\hline Sl.no & Variables & Categories & Frequency & Percentage \\
\hline \multirow[t]{3}{*}{1} & \multirow{3}{*}{ Age } & Young (Up to 35 ) & 12 & 20.0 \\
\hline & & Middle (36-45) & 20 & 33.33 \\
\hline & & Old (Above 45) & 28 & 46.67 \\
\hline \multirow[t]{2}{*}{2} & \multirow[t]{2}{*}{ Sex } & Male & 29 & 48.30 \\
\hline & & Female & 31 & 51.70 \\
\hline \multirow[t]{7}{*}{3} & \multirow{7}{*}{ Education } & Illiterate & 22 & 36.70 \\
\hline & & Can read only & 3 & 5.00 \\
\hline & & Can read and write & 2 & 3.30 \\
\hline & & Primary school & 14 & 23.30 \\
\hline & & Middle school & 18 & 30.00 \\
\hline & & High school & 1 & 1.70 \\
\hline & & College and above & 0 & 0 \\
\hline \multirow[t]{2}{*}{4} & \multirow[t]{2}{*}{ Family type } & Nuclear family & 47 & 78.30 \\
\hline & & Joint family & 13 & 21.70 \\
\hline \multirow[t]{2}{*}{5} & \multirow[t]{2}{*}{ Family size } & Up to 5 members & 47 & 78.30 \\
\hline & & More than 5 members & 13 & 21.70 \\
\hline \multirow[t]{3}{*}{6} & \multirow[t]{3}{*}{ Occupation } & Dairying alone & 13 & 21.67 \\
\hline & & Dairying + Agriculture & 31 & 51.67 \\
\hline & & Dairying + Agriculture+ Others & 16 & 26.66 \\
\hline \multirow[t]{4}{*}{7} & \multirow[t]{4}{*}{ Land holding } & Landless & 16 & 26.70 \\
\hline & & Marginal (Up to 2.5 acres) & 24 & 40.00 \\
\hline & & Small (2.51 to 5.00 acres) & 12 & 20.00 \\
\hline & & Large (More than 5 acres) & 8 & 13.30 \\
\hline \multirow[t]{3}{*}{8} & \multirow{3}{*}{$\begin{array}{l}\text { Farming } \\
\text { experience }\end{array}$} & Low (Up to 5 years) & 12 & 20.00 \\
\hline & & Medium (6-10 years) & 21 & 35.00 \\
\hline & & High (More than 10 years) & 27 & 45.00 \\
\hline \multirow[t]{3}{*}{9} & \multirow{3}{*}{$\begin{array}{l}\text { Livestock } \\
\text { possession } \\
(2.89 \pm 1.57)\end{array}$} & Low & 11 & 18.33 \\
\hline & & Medium & 41 & 68.33 \\
\hline & & High & 8 & 13.34 \\
\hline \multirow[t]{5}{*}{10} & \multirow{5}{*}{$\begin{array}{l}\text { Social } \\
\text { participation }\end{array}$} & No membership & 0 & 0 \\
\hline & & Member in one organisation & 45 & 75.00 \\
\hline & & $\begin{array}{l}\text { Membership in more than one } \\
\text { organisation }\end{array}$ & 15 & 25.00 \\
\hline & & Office bearer in one organisation & 0 & 0 \\
\hline & & Office bearer in more than one organisation & 0 & 0 \\
\hline \multirow[t]{3}{*}{11} & \multirow{3}{*}{$\begin{array}{l}\text { Extension } \\
\text { participation } \\
(1.20 \pm 0.48)\end{array}$} & Low & 30 & 50.00 \\
\hline & & Medium & 25 & 41.67 \\
\hline & & High & 5 & 8.33 \\
\hline \multirow[t]{3}{*}{12} & \multirow{3}{*}{$\begin{array}{l}\text { Cosmopoliteness } \\
(1.02 \pm 0.27)\end{array}$} & Low & 5 & 8.33 \\
\hline & & Medium & 51 & 85.00 \\
\hline & & High & 4 & 6.67 \\
\hline \multirow[t]{3}{*}{13} & Innovativeness & Adopt an innovations as soon as it & 2 & 3.33 \\
\hline & & $\begin{array}{l}\text { Adopted innovations after seeing the } \\
\text { adoption of other farmers }\end{array}$ & 44 & 73.34 \\
\hline & & Preferred to wait and taken their own time & 14 & 23.33 \\
\hline
\end{tabular}


Table. 2 Constraints encountered by dairy farmers in dairying $(n=60)$

\begin{tabular}{|c|c|c|c|c|}
\hline Sl.No & Constraints & $\begin{array}{l}\text { Garrets } \\
\text { Score }\end{array}$ & $\begin{array}{c}\text { Garret's } \\
\text { average score }\end{array}$ & Rank \\
\hline 1 & $\begin{array}{l}\text { Lack of knowledge in latest farming } \\
\text { technologies }\end{array}$ & 3937 & 65.62 & $\mathbf{I}$ \\
\hline 2 & Scarcity of grazing land and water & 3807 & 63.45 & II \\
\hline 3 & $\begin{array}{l}\text { Lack of veterinary extension services at field } \\
\text { level }\end{array}$ & 3603 & 60.05 & III \\
\hline 4 & $\begin{array}{l}\text { Lack of knowledge on available information } \\
\text { sources }\end{array}$ & 3293 & 54.88 & IV \\
\hline 5 & High cost of veterinary treatment services & 3083 & 51.38 & $\mathbf{V}$ \\
\hline 6 & Lack of veterinary services at door step & 2915 & 48.58 & VI \\
\hline 7 & Lack of knowledge on diseases and vaccination & 2591 & 43.18 & VII \\
\hline 8 & Lack of knowledge about government schemes & 2577 & 42.95 & VIII \\
\hline 9 & Lack of credit facility & 2482 & 41.37 & IX \\
\hline 10 & Limited contact with scientists & 2356 & 39.27 & $\mathbf{X}$ \\
\hline
\end{tabular}

High cost of veterinary services (51.38), lack of veterinary services at door step (48.58) and lack of knowledge of diseases and vaccination (43.18) were ranked fifth, sixth and seventh constraints respectively. Veterinary services like treatment of the diseases like mastitis, acidosis, anestrus and repeat breeders have resulted in heavy economic losses faced by the dairy farmers in the study area. Treatment cost is also one of the major constraints perceived by the farmers. Farmers need immediate door step veterinary services at the time of emergency situation like uterine prolapse and dystocia cases.

Lack of knowledge about government schemes (42.95), inadequate credit facility (41.37)and limited contact with scientists (39.27) were ranked subsequently in that order. Eqbal et al., (2013) also reported that lack of credit facilities for purchase of feeds, fodders and mineral mixture as the major constraint faced by respondents. It could be enhanced by conducting regular interaction programmes between scientist and farmers, so that farmers may directly get the latest dairy technologies and dairying related informations. Efforts could be made by Government functionaries to educate farmers to seek the knowledge about dairying related government schemes.

Inadequate formal credit facilities could lead to borrowing money from local money lenders at high rates of interest for purchasing farm inputs and create burden to the farmers. Banks and dairy co-operatives could help the farmers for providing low interest credit facilities for purchase of animals, feeds and farm equipments.

The study indicated that lack of knowledge in latest technologies, scarcity of grazing land and water, lack of veterinary extension services at field level and lack of knowledge of available information as the most important constraints perceived by the dairy farmers in the study area. Farmers should be made to adopt the scientific farming practices through extension approaches which will lead to better future outcome for farmers. The price offered for the sale of milk should be increased which 
in turn helps farmer to improve socioeconomic status and larger productivity.

\section{Acknowledgement}

The authors are thankful to dairy farmers and Veterinary Assistant Surgeons of Cuddalore district, Tamil Nadu for providing necessary assistance to carry out the work.

\section{References}

Annual Report. 2017-18. Department of Animal Husbandry, Dairying and Fisheries. Ministry of Agriculture and Farmers Welfare, Govt. of India, New Delhi.

Chandrasekar, G.K., Satyanarayan, K., Jagadeeswary, V. and Shree. J. S.2017. Relationship between socioeconomic and psychological factors of dairy farmers with days open - A study in Rural Karnataka. International Journal of Pure \& Applied Bioscience, 5(1): 171-177.

Eqbal, M.S., Singh, M.K. and Khan. N. 2013.
Constraints faced by tribal dairy farmers regarding dairy farming practices in Lohardaga district of Jharkhand. International Journal of Scientific Research, 2(6): 546-548.

Garrett, E.H. and Woodworth.R.S.1969. Statistics in psychology and education. Vakils, Feffer and Simons Private Limited., Bombay: 329.

Government of India (GOI). 2014. Basic Animal Husbandry Statistics. Ministry of Agriculture and Farmers Welfare, Department of Animal Husbandry, Dairying and Fisheries. New Delhi.

Kalaivani, S.R., Sakthivel, K.M., Narmatha, N., Thirunavukkarasu, D. and Uma. V.2017.Socio-economic and psychological characteristics of dairy contract farmers. Indian Journal of Animal Health, 56(2): 203-210.

Manivannan, A. 2008. Livestock farming systems in Tamil Nadu. Unpublished $\mathrm{Ph} . D$. thesis, Tamil Nadu Veterinary and Animal Sciences University, Chennai.

\section{How to cite this article:}

Gopi, R, A. Manivannan, M. G. Sindhu and Soundararajan, C. 2020. Socio- Economic Profile and Constraints of Dairy Farmers in Cuddalore District of Tamil Nadu, India. Int.J.Curr.Microbiol.App.Sci. 9(04): 1320-1326. doi: https://doi.org/10.20546/ijcmas.2020.904.156 